Jurnal Ilmu-Ilmu Peternakan 26 (3): 1 - 5

ISSN : 0852-3681

E-ISSN : 2443-0765

OFakultas Peternakan UB, http://jiip.ub.ac.id/

\title{
Tepung temu hitam (Curcuma aeruginosa Roxb) dalam ransum mem- perbaiki produktifitas dan High Density Lipoprotein (HDL) serum itik pedaging Peking
}

\author{
A. A. Syaefudin, R. Murwani dan Isroli \\ Fakultas Peternakan dan Pertanian, Universitas Diponegoro, Semarang \\ Jalan Kalitaman Krajan Wujil Kec. Bergas Kab. Semarang Jawa Tengah \\ ghanisyaifudin@gmail.com
}

\begin{abstract}
The purpose of this research was to determine the effect of Curcuma Aeruginosa Roxb.(C. Aeruginosa) powder addition on serum lipid (total cholesterol, LDL, HDL and triglycerides) and productivity of Peking duck. The material of the study were one hundred and twenty peking ducks aged 2 days old with initial body weight $\pm 65 \mathrm{~g}$. The experiment applied a completely randomized design with 5 treatments and 4 replications. Each replication consisted of 6 ducks. The treatment consisted of T0 $=0 \% C$. Aeruginosa powder, $\mathrm{T} 1=0.75 \% C$. aeruginosa powder, $\mathrm{T} 2=1 \% C$. aeruginosa powder, $\mathrm{T} 3=1.25 \%$ C. aeruginosa powder and $\mathrm{T} 4=1.5 \%$ C. aeruginosa powder. Comercial diet with $23 \%$ protein was given from day 2 to day 14 while day 15 ducks were given diet with $17.5 \%$ protein and $3029.7 \mathrm{kcal} / \mathrm{kg}$ metabolic energy. Curcuma aeruginosa powder was given on day 25 to day 57 . Daily consumption was recorded and body weight was recorded once a week. Both samples were taken on day 57 . The data were processed by ANOVA at $\mathrm{P}=0.05$. The results showed that addition of $1.25 \%$ C.Aeruginosa powder (T3) had the lowest consumption, higher body weight and body weight gain (BWG) with lowest feed conversion. Curcuma aeruginosa powder only affected significantly the HDL. All groups with $C$. aeruginosa addition showed higher HDL than control group. It can be concluded that addition of 1,25\% (T3) C. Aeruginosa powder will produced the highest serum HDL, and provide better productivity.
\end{abstract}

Keywords: C. aureginosa, Peking duck and serum lipid

\section{PENDAHULUAN}

Itik Peking merupakan itik pedaging yang dapat dipotong pada umur 53 hari dengan bobot kurang lebih 2-4 kg. Itik Peking dengan konsumsi 701,23 g/ekor/ minggu dapat mencapai PBB 248,92 g/ekor/ minggu dan konversi ransum 3,93 (Saleh dkk., 2006). Hal ini membuat itik Peking sebagai salah satu jenis unggas air yang cukup bagus sebagai penghasil daging. Itik Peking dikenal memiliki kandungan lemak tinggi pada dagingnya sehingga perlu diturunkan untuk memenuhi permintaan konsumen yang menginginkan produk daging itik rendah lemak. Penurunan kadar lemak pada itik Peking dapat dilakukan dengan penambahan bahan pakan dari tanaman obat lokal, salah satunya temu hitam.

Temu hitam (Curcuma aeruginosa) mengandung minyak atsiri yang berpotensi menurunkan lemak, sehingga diharapkan dapat menurunkan kadar 
lemak yang ada pada daging tersebut. Manfaat lain yaitu dapat menambah nafsu makan pada ternak dan sebagai obat cacing. Penekanan kadar lemak darah disertai nafsu makan yang meningkat diharapkan dapat menghasilkan itik yang berproduksi tinggi dengan kandungan lemak yang rendah pada dagingnya. Lemak daging dipasok oleh lemak darah sehingga penelitian ini bertujuan mengetahui penambahan tepung temu hitam dalam ransum terhadap kadar lemak darah (kolesterol total, LDL, HDL dan trigliserida) dan tampilan produksinya. Harapan dari penelitian ini adalah pemberian temu hitam yang mengandung minyak atsiri dapat menurunkan lemak darah dan meningkatkan produktifitasnya.

\section{MATERI DAN METODE}

Penelitian ini dilaksanakan 31 Desember 2015 hingga 1 Februari 2016 di Fakultas Peternakan dan Pertanian Universitas Diponegoro,Semarang. Penelitian ini menggunakan 120 itik umur 2 hari dengan bobot awal \pm 65 gram. Pakan yang digunakan memiliki kandungan nutrisi sebagai Tabel 1.

Tabel 1. Kandungan nutrisi pakan

\begin{tabular}{lccc}
\hline \multicolumn{1}{c}{ Kandungan nutrisi } & Ransum sendiri (\%) & Ransum komersil (\%) & Temu hitam (\%) \\
\hline Protein kasar & 17,54 & 23 & 4,43 \\
Lemak kasar & 4,26 & 5 & 4,89 \\
Serat kasar & 5,82 & 5 & 0,84 \\
Ca & 0,88 & - & 17,8 \\
P & 0,37 & 0,6 & 10,69 \\
EM (kkal/kg) & 3029,72 & - & - \\
Lisin & 0,65 & - & - \\
Metionin & 0,30 & - & - \\
Abu & - & 7 & - \\
Kalsium & - & 0,9 & - \\
Kadar air & - & 13 & - \\
Minyak atsiri & - & - & 1 \\
Premix & 1 & - & - \\
\hline
\end{tabular}

Metode penelitian yang digunakan terdiri dari tiga tahapan, yakni tahap pembuatan tepung temu hitam, pemberian tepung temu hitam, dan pengambilan data. Tahap pembuatan tepung temu hitam yaitu rimpang pada temu hitam diparut sampai lembut kemudian dijemur atau dimasukkan ke dalam oven saat hujan dan malam hari sampai kering. Rimpang yang sudah halus dan kering udara diblender sampai halus membentuk tepung kemudian disimpan dalam karung. Tepung temu hitam diberikan dengan menimbang terlebih dahulu tepung temu hitam untuk setiap perlakuan kemudian mencampurkan dalam ransum buatan sendiri.
Ransum yang telah tercampur dengan tepung temu hitam diberikan kepada itik dilaksanakan setiap pagi. Itik diberi tepung temu hitam pada umur 25-57 hari (32 hari). Berikut ini dosis pemberian tepung temu hitam pada ransum:

$\mathrm{T}_{0}=$ Ransum tidak ditambah dengan tepung temu hitam

$\mathrm{T}_{1}=$ Ransum ditambah dengan tepung temu hitam $0,75 \%$

$\mathrm{T}_{2}=$ Ransum ditambah dengan tepung temu hitam $1 \%$

$\mathrm{T}_{3}=$ Ransum ditambah dengan tepung temu hitam 1,25\%

$\mathrm{T}_{4}=$ Ransum ditambah dengan tepung temu hitam $1,5 \%$

Pengambilan data meliputi kon- 
sumsi, bobot badan dan pengambilan darah. Data konsumsi pakan diambil setiap pagi setelah pemberian pakan dengan menimbang pakan sisa pemberian sebelumnya. Data bobot badan diambil setiap minggu dengan melakukan penimbangan pada ternak. Pengambilan darah diambil pada hari ke-57 pada pagi hari dan dianalisis ke Laboratorium. Perhitungan Pertambahan Bobot Badan Harian (PBBH) yaitu bobot akhir ternak dikurangi dengan bobot awal ternak dibagi 57 hari (lama pemeliharaan). Konversi ransum dihitung dengan konsumsi ternak dibagi dengan $\mathrm{PBBH}$.
Rancangan percobaan yang digunakan adalah Rancangan Acak Lengkap (RAL) yang terdiri dari 5 perlakuan dan 4 ulangan. Setiap ulangan terdiri dari 6 ekor itik Peking. Data yang diperoleh diuji normalitas dan analisis ragam, apabila terdapat pengaruh perlakuan yang nyata dilanjutkan dengan Uji Jarak Berganda Duncan (UJBD).

\section{HASIL DAN PEMBAHASAN}

\section{Tampilan produksi}

Hasil tampilan produksi dan profil lemak pada penelitian ini disajikan pada Tabel 2.

Tabel 2. Tampilan produksi dan profil lemak darah itik Peking

\begin{tabular}{|c|c|c|c|c|c|}
\hline \multirow{2}{*}{$\begin{array}{l}\text { Tampilan } \\
\text { produksi }\end{array}$} & \multicolumn{5}{|c|}{ Perlakuan } \\
\hline & T0 $(0 \%)$ & T1 $(0,75 \%)$ & $\mathrm{T} 2(1 \%)$ & $\mathrm{T} 3(1,25 \%)$ & $\mathrm{T} 4(1,5 \%)$ \\
\hline $\begin{array}{l}\text { Konsumsi } \\
\text { (g/ekor/hari) }\end{array}$ & $167,01 \pm 1,36^{\mathrm{a}}$ & $166,37 \pm 1,8^{a}$ & $165,59 \pm 1,55^{\mathrm{ab}}$ & $165,38 \pm 0,54^{\mathrm{ab}}$ & $163,08 \pm 1,9^{b}$ \\
\hline $\begin{array}{l}\text { Bobot badan } \\
\text { (g/ekor) }\end{array}$ & $1785,88 \pm 84,51^{b}$ & $1736,04 \pm 89,43^{b}$ & $1929,17 \pm 151,50^{\mathrm{a} b}$ & $2041,67 \pm 57,53^{a}$ & $2044,38 \pm 97^{\mathrm{a}}$ \\
\hline $\begin{array}{l}\text { PBBH } \\
\text { (g/ekor/hari) }\end{array}$ & $30,10 \pm 1,5^{b}$ & $29,22 \pm 1,60^{b}$ & $32,66 \pm 2,71^{\mathrm{ab}}$ & $34,67 \pm 1,03^{\mathrm{a}}$ & $34,72 \pm 1,73^{\mathrm{a}}$ \\
\hline $\begin{array}{l}\text { Konversi pa- } \\
\text { kan }\end{array}$ & $5,56 \pm 0,26^{\mathrm{a}}$ & $5,73 \pm 0,30^{\mathrm{a}}$ & $5,09 \pm 0,37^{\mathrm{bc}}$ & $4,77 \pm 0,16^{\mathrm{c}}$ & $4,71 \pm 0,29^{c}$ \\
\hline \multicolumn{6}{|c|}{ 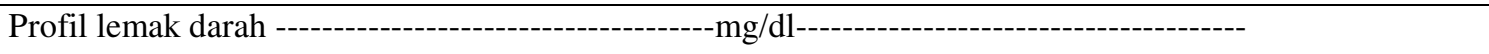 } \\
\hline $\begin{array}{l}\text { Kolesterol } \\
\text { HDL }\end{array}$ & $\begin{array}{l}216,7 \pm 21,3 \\
56,6 \pm 7,27^{\mathrm{b}}\end{array}$ & $\begin{array}{l}225 \pm 29,2 \\
89,1 \pm 18,10^{a}\end{array}$ & $\begin{array}{l}227,8 \pm 27,9 \\
94,05 \pm 12,10^{a}\end{array}$ & $\begin{array}{l}230,6 \pm 49,2 \\
95,7 \pm 22,26^{a}\end{array}$ & $\begin{array}{l}255,6 \pm 28,7 \\
73,1 \pm 8,50^{\mathrm{a} b}\end{array}$ \\
\hline LDL & $125,7 \pm 18,81$ & $92,3 \pm 56,53$ & $95,9 \pm 42,73$ & $104,8 \pm 56,5$ & $149,5 \pm 23,3$ \\
\hline Trigliserida & $171,4 \pm 30,86$ & $217,9 \pm 81,96$ & $189,3 \pm 61,03$ & $150 \pm 24,74$ & $164,3 \pm 35,95$ \\
\hline
\end{tabular}

Keterangan : Huruf kecil di belakang angka pada baris yang sama menunjukkan berbeda nyata $(\mathrm{P}<0,05)$.

Tabel 2 menunjukkan bahwa Tepung temu hitam berpengaruh nyata $(\mathrm{P}<0,05)$ terhadap konsumsi, $\mathrm{PBBH}$, bobot badan dan konversi pakan pada itik Peking. Pada taraf 1,25\% (T3) dan $1,5 \%$ (T4), penambahan tepung temu hitam memberikan konversi pakan dan konsumsi terendah. Rendahnya konversi pakan membuktikan efisiensi dalam penggunaan nutrisi dari ransum sehingga meningkatkan bobot badan. Hal ini kemungkinan karena kandungan senyawa aktif curcumin dan minyak atsiri yang terdapat dalam tepung temu hitam. Zat tersebut dapat mempengaruhi gerak paristaltik usus dan melancarkan pencernaan sehingga nutrisi dapat terserap lebih baik (Rukmana, 2005; Sutrisna, 2011). Hal tersebut didukung oleh penelitian Mehr et al., (2014) yang mendapatkan hasil minyak atsiri dapat memberikan efek positif pada proses pencernaan yakni dengan meningkatnya kerja organ pencernaan bisa merangs- 
ang dinding empedu mengeluarkan cairan empedu dan merangsang keluarnya getah pangkreas yang mengandung enzim amilase, lipase dan protease untuk meningkatkan pencernaan pada karbohidrat, lemak dan protein.

\section{Profil lemak darah}

Berdasarkan Tabel 2 diketahui bahwa pemberian tepung temu hitam berpengaruh nyata $(\mathrm{P}>0.05)$ terhadap kandungan HDL dan tidak berpengaruh terhadap kolesterol total, trigliserida dan LDL darah itik Peking. Hal tersebut disebabkan karena jumlah zat aktif minyak atsiri belum mampu membantu menurunkan kadar trigliserida. Hasil yang sama juga ditemukan pada penelitian Pratama dkk., (2012) dimana penambahan tepung jahe yang memiliki kandungan minyak atsiri tidak berpengaruh terhadap trigliserida. Pada pemberian tepung temu hitam tidak berpengaruh terhadap kolesterol dan LDL karena Very Low Density Lipoprotein (VLDL) yang mengandung trigliserida, lipoprotein dan kolesterol dan disekresi oleh hati ke darah trigliseridanya dipecah sebagian oleh enzim lipoprotein lipase dan digunakan oleh jaringan. Sisa VLDL setelah trigliseridanya dipecah menjadi LDL yang kaya kolesterol (Murwani, 2009). Kolesterol dalam LDL diambil oleh jaringan dan LDL kembali ke hati (Murwani, 2009). Kadar kolesterol seiring dengan kadar LDL karena sebagai pembawa kolesterol sehingga bila kadar kolesterol tetap maka LDL juga tidak berubah.

Tidak adanya pengaruh tepung temu hitam terhadap LDL dan kolesterol serum kemungkinan karena kandungan minyak atsiri temu hitam lebih sedikit dibandingkan dengan temulawak, temu putih, temu kunci dan jahe. Kadar minyak atsiri rimpang temu ireng $0,5-1 \%$, temu giring $1-1,5 \%$, temu mangga $2-2,5 \%$, temu glenyeh $2-3 \%$, temulawak 4-6\%, temu putih $1-1,5 \%$, rimpang jahe 1,5-3\% dan temu kunci 1\% (Ahmad, 2003; Kurniasari dkk., 2008; Hayani, 2007). Kandungan minyak atsiri temu hitam lebih sedikit dibandingkan dengan temulawak, temu putih, temu kunci dan jahe sehingga tidak ada pengaruh terhadap kadar kolesterol, trigliserida dan LDL dalam serum.

Tabel 2 menunjukkan bahwa pemberian tepung temu hitam dapat mempengaruhi kadar HDL. Pada taraf $1,25 \%$ tepung temu hitam (T3) memiliki kadar HDL dalam serum paling tinggi dibandingkan dengan perlakuan lainnya. Hal ini kemungkinan disebabkan oleh zat aktif minyak atsiri dan curcumin dapat meningkatkan gerak peristaltik usus (Rositawati dkk., 2010). Meningkatnya gerak peristaltik memperbanyak kehilangan garam empedu di duodenum sehingga hati membutuhkan kolesterol lebih banyak untuk menghasilkan garam empedu. Produksi garam empedu memerlukan kolesterol, jika cadangan kolesterol di hati tidak memenuhi maka HDL akan diperlukan untuk mengangkut kolesterol dari jaringan ke hati dan akan memicu meningkatnya kadar HDL (Hartoyo dkk., 2005). Hasil penelitian yang sama oleh Mehr et al., (2014) menunjukkan bahwa minyak atsiri pada cengkeh dengan dosis $450 \mathrm{ppm}$ mampu meningkatkan kadar HDL ayam broiler.

\section{KESIMPULAN}

Berdasarkan hasil penelitian dapat disimpulkan bahwa pemberian $1,25 \%$ tepung temu hitam (T3) mampu merubah kadar HDL menjadi lebih tinggi dan menghasilkan konsumsi yang rendah dan konversi yang rendah dengan bobot badan dan PBBH pada tampilan produksinya lebih baik dibandingkan taraf $0 \%, 0,5 \%, 0,75 \%$, $1 \%$, dan $1,5 \%$. 
DAFTAR PUSTAKA

Ahmad, D. S. 2003. Keanekaragaman kandungan minyak atsiri rimpang temu-temuan (Curcuma). J. Biofarm. 1 (2): 44-49. Surakarta. Hartoyo, B., I. Irwan., dan Ning. I. 2005. Pengaruh asam lemak dan serat kasar yang berbeda dalam ransum broiler terhadap kandunga kolesterol, HDL dan LDL serum darah. Anim. Prod. 7 (1): 27-33.

Hayani, E. 2007. Pemisahan komponen rimpang temu kunci secara kromatografi kolom. Buletin Teknik Pertanian. 12 (1): 35-37.

Kurniasari, H. I., L., Ratnani, R. D., dan Sumantri, I. 2008. Kajian ekstraksi minyak jahe menggunakan Microxave Assited Extraction (MAE). Momentum. 4 (2): 47-50.

Mehr, M. A., Hassanabdi, A., Nassiri, M., and Kermanshahi. 2014. Suplementasi of clove essential oil and probiotic to the broiler's on performance, carcass and blood components. J. Appl Anim Sci. 4 (1): 117-122.
Murwani, R. 2009. Broiler modern. Widya Karya. Semarang.

Pratama, A. Y., Umiyati A., dan Luthfi D. M,. 2012. Pengaruh penggunaan tepung jahe (Zinger offinale) dalam ransum terhadap perlemakan dan trigliserida ayam kampung. J. Anim Agric. 1 (1): 733-741.

Rukmana. 2005. Temu hitam. Kanisius. Yogyakarta.

Rositawati, I., Saifut, N., dan $\mathrm{Mu}-$ harlien. 2010. Upaya peningkatan performa itik Mojosari periode starter melalui penambahan temulawak (Curcuma xanthoriza, Roxb) pada pakan. J. Ternak Tropika. 11 (2): 32-40.

Saleh, E., Tri, H., dan Ganda. P. S. 2006. Pemberian tepung bawang putih (Allium sativum L.) dalam ransum terhadap performas itik Peking umur 1-8 minggu, Sumatra Utara. J. Agribisnis Peternakan. 2 (3): 96-100.

Sutrisna, R. 2011. Pengaruh beberapa tingkat serat kasar dalam ransum terhadap perkembangan organ dalam itik jantan. J. Penelitian Pertanian Terapan. 12(1): 1-5. 